\title{
E-procurement in Contracting-out of Public Goods and Services: Evidence from Slovakia
}

Mária Murray Svidroňová, Beáta Mikušová Meričková, Lýdia Gondášová ${ }^{1}$

\begin{abstract}
Recently growing attention has been paid to the issue of public-sector innovation: scholars have progressively developed a fully-fledged field of study in this direction, since remarkable differences exist between public and private organizations. Perhaps paradoxically, the decline of NPM itself from the 1990s onwards has paved the way to further developments of this field of study, surpassing the existent model through the exploration of innovative tools for stakeholders' involvement in public decision-making. New Public Management reforms of public administration combined with the use of information and communication technologies have brought many innovations to the public sector, among others also public e-procurement. Our objective is to identify the driver and barriers of e-procurement use in contracting-out of public goods and services based on analysis in one selected region and its four municipalities in Slovakia. This study uses a qualitative and quantitative approach and is based on original data from our own research, including data collected within the LIPSE (Learning from Innovation in Public Sector Environments) research project. The main findings of our analysis are that the use of public e-procurement is an innovative tool for contracting out the public services and as such facilitates modern public-administration reforms based on information and communication technologies.
\end{abstract}

\section{Key words:}

E-procurement, e-auctions, innovations in public services, public-sector innovations

1 Department of Public Economics and Regional Development, Matej Bel University in Banska Bystrica, Banska Bystrica, Slovakia, E-mail, respectively, maria.svidronova@umb.sk, beata.mikusovamerickova@umb.sk and lydia-gondasova@umb.sk 


\section{Introduction}

E-procurement brings several benefits, EC (2010) includes the following among the main advantages: increased accessibility and transparency; benefits for individual procedures; benefits in terms of more efficient procurement administration and potential for integration of EU procurement markets. Other authors (e.g. Murray Svidroňová and Mikuš 2015) add the following advantages of e-procurement: improvement of the quality and flexibility of services; decrease of service prices and variability; a solution for information asymmetry; increase of a competitive effect; increase in time savings; an easy and fast spread of information about e-auctions and their progress; opening the markets also for foreign companies to participate and reducing the level of bureaucracy. The World Bank points out in its study that the public sector in Brazil, by using electronic auctions, saved $19-21 \%$ of the total value of the public procurement (World Bank 2010, 51). Joia and Zamot (2002, 9), eight years before the publication of the World Bank official study, report savings in e-auctions in Brazil of up to $30 \%$. Mereles $(2012,3)$ indicates in his case study that in 2011 the public sector in Paraguay saved about $12 \%$ of the value of contracted service by electronic auctions in only the third year of their use. Wyld $(2011,5)$ reports $10 \%$ savings on e-auctions in the conditions of the public-sector organizations in the United States. Sashi and O'Leary $(2002,105)$ indicate in their study on the USA that electronic auctions can, of course depending on the procurer, save up to $20 \%$ of the initial value. Public-sector organizations in the UK recorded $25 \%$ savings (Major 2003, 10). E-auctions savings in conditions of the European Union, analyzed by the European Commission (European Commission 2010, 5), differ in various EU countries, e.g. Austria yielded less than $3 \%$ savings, Norway on the other hand had between 2 and $10 \%$ savings. Other researchers focusing on the issue of e-procurement from Slovakia and the Czech Republic have come to similar conclusions, i.e. the e-procurement has the potential to reduce the risks associated with contracting out public goods and services and increases economy and efficiency in public procurement (Špaček and Malý 2010; Hvozdíková et al. 2011; Trenkler 2011; Sičáková-Beblavá et al. 2011; Murray Svidroňová and Mikuš 2015; Pavel and Sičáková-Beblavá 2008; Pavel et al. 2013 etc.). In the research of Sičáková-Beblavá et al. $(2011,32)$ it is shown that savings of public-sector organizations by using electronic auctions in Slovakia range between 6 and $12 \%$. However, the ability to perform procurement electronically requires investment throughout the procurement chain to build the necessary capacity and manage the change-over. Investment costs in national and regional e-Procurement facilities - spanning e-portals to more comprehensive solutions - range from $0.5 \mathrm{~m} €$ to $5 \mathrm{~m} €$. Maintenance costs vary from several thousand euros to several million, presumably depending on the size and sophistication of the system. Experience suggests these investments can be recouped in administrative savings within short time frames. However, the bigger barrier to the use of these systems lies in encouraging contracting authorities and 
supplier communities to work with these new systems (Coombes and Verheijen 1997; Covaleski et al. 2005; Christensen and Lægreid 2001, Ochrana et al. 2008, Nemec 2010). There are several economic, social, political and demographic factors of the outer context that determine the use of public e-procurement, as well as organizational, individual and technological factor of the inner context of concrete institution (Nemec and Murray Svidroňová 2016, LIPSE research project methodology). These factors create the drivers and barriers of e-procurement implementation and use. The objective of this study is to identify the drivers and barriers of e-procurement use in Slovak municipalities.

\section{Theoretical background}

Over the past 15 years, an enormous effort has been put into the development of e-government. This is due to the fact that e-government has become one of the priority fields within the national (and international) development strategies, e.g. the EU Action Plan (Benčina and Jukić 2015). Connecting e-government with the policy-making process aims at helping to establish a trust-based relationship among citizens, policy makers, civil servants and other stakeholders, so as to balance the precision in the measurement of the impacts of e-Government projects with a more transparent and participatory assessment process since the early stage of the policymaking cycle (Savoldelli et al. 2013). The impact of e-government in relation to public-value creation is a subject of several researchers, e.g. Jukić et al. 2013; Welch et al. 2005; Savoldelli et al. 2013 or Hardy and Williams 2008. Twum Darko (2014) argues that actor-network theory is used as a lens to provide an understanding and interpretation of not only the process and interactions between actors but also of the meanings that people assign to the form of interactions between actors to align diverse interests. In the e-government context the non-human elements could be policies, technology, government services etc. Actors, whether human or non-human, have interests which they pursue. According to Tatnall and Gilding (1999) actors do not define themselves, but are defined by the relations to other actors in the network. The trend that emerged from the literature is that there is a strong relationship between the level of e-government readiness and the success (or even the improvement) of the implementation of e-government projects. This implies that the higher the level of readiness the more sustainable the network of aligned interest. The higher the e-government readiness, the more successful the implementation will be. This includes e-procurement implementation as well, which is aimed at transparency increase.

Transparency requires all processes in the public sector to be transparent and thus able to be evaluated by society, which reduces the possibility of corruption and improper performance of public competences (Meričková et al. 2005, Michalski 2008). Transparency of public procurement allows the implementation of an open decision that can be re-verified and logically explained. Transparency concerns all 
the phases of public procurement - the announcement of a public procurement (call for tenders); the disclosure of the relevant conditions, the establishment of criteria for decision-making and deadlines. Lack of transparency can discourage participation of partners from the private sector in public procurement (Kuvíková and Vaceková 2009; Gavurová et al. 2014). Transparency can be negatively affected mainly by a poor (incomplete) announcement of the procurement process, bidders' discrimination, non-compliance with the Public Procurement Act, the absence of budgetary constraints and corruption. Information about a particular public procurement is made available through a call for tenders. The procurer can systematically favour some bidders by a lack of information and unclear procedures for the ordering of public contracts. The lack of information makes it impossible to comply with the principle of transparency.

Discrimination against public-procurement applicants (bidders) indirectly reduces transparency, thereby creating various possibilities for interpreting publicprocurement conditions and criteria, in turn creating opportunities for the emergence of bribes, corruption and other problems. With the growing corruption the expenditure on the implementation of public-procurement contracts also grows, whereas the number of applicants for public procurements declines, particularly from among small and medium-sized enterprises (SMEs) that do not have the funds to pay bribes. The most significant source of opacity and subsequent corruption can simply be considered the failure to follow the regulations on public procurement. And in some cases we can even talk about hindering SMEs by public procurement (Loader 2011).

Act No. 25/2006 Coll. on Public Procurement in Slovakia, as amended, prescribes for the form for the mandatory announcement of the public-procurement. This procedure announcement is binding for the whole of the subsequent publicprocurement process, in particular in determining the contract subject, the conditions for participation in the competition and the criteria for evaluating the winning bid. These can then no longer be changed, neither in the specifications of procurement documents nor in the evaluation of bids. One of the most important tools for a successful and fair public procurement in the selection phase is to develop clear and understandable specifications of procurement documents. Incorrect, unclear, imprecise and generally incomprehensible documents are sources for nontransparency in public procurement and therefore a possible source of bribery and corruption. Based on several research projects and experiences of the authors in the field of public procurement (Ochrana et al. 2008, Nemec 2010, Meričková et al. 2005, Tátrai 2015; Murray 2012 and 2014), the level of specifications of procurement documents in Slovakia is astoundingly low, especially in terms of the inadequate qualifications of the procurement authorities and in some cases also the deliberately botched preparation of the documents (the procurers thus create space for themselves to change the contract subject or the contract price after closing the 
contract - changes in content of contracts and prices are among the most common violations of the Public Procurement Act).

\section{Table 1}

Types of e-auctions

\begin{tabular}{|c|c|c|}
\hline Criteria & $\begin{array}{l}\text { Type of } \\
\text { e-auction }\end{array}$ & Characteristics \\
\hline \multirow[b]{2}{*}{$\begin{array}{l}\text { Based on a contract } \\
\text { "price maker" (bidder) }\end{array}$} & Forward & $\begin{array}{l}\text { Auction with one seller and many buyers (Tur- } \\
\text { ban 2006). }\end{array}$ \\
\hline & Reverse & $\begin{array}{l}\text { Opposite of English auction (Delina and Vajda } \\
\text { 2008). Procurer places a request for delivery } \\
\text { of the goods. Subsequently they receive offers } \\
\text { with decreasing values. }\end{array}$ \\
\hline \multirow{2}{*}{$\begin{array}{l}\text { Based on publicity I. } \\
\text { (Delina and Vajda 2008; } \\
\text { Sičáková Beblavá et al. } \\
\text { 2011) }\end{array}$} & Open & Anyone interested may participate. \\
\hline & Closed & $\begin{array}{l}\text { Participation is strictly limited to invitation } \\
\text { from the contracting authority. }\end{array}$ \\
\hline \multirow{2}{*}{$\begin{array}{l}\text { Based on publicity II. } \\
\text { (Wenyan and Bolivar } \\
\text { 2008) }\end{array}$} & Public & Identity of participants is known. \\
\hline & Private & $\begin{array}{l}\text { Identity of participants as well as the winner } \\
\text { is secret. }\end{array}$ \\
\hline $\begin{array}{l}\text { Based on position of win- } \\
\text { ning bid (Wenyan and Bo- } \\
\text { livar 2008; Krishna 2010; } \\
\text { Turban 2006; Narahari } \\
\text { and Guyar 2010) }\end{array}$ & $\begin{array}{l}\text { First, second, } \\
\text { third (...) offer } \\
\text { wins }\end{array}$ & $\begin{array}{l}\text { In order to avoid speculative reduction of the } \\
\text { contract price, it can be determined that the } \\
\text { winning bid is not the lowest priced, but, for } \\
\text { example the second or third lowest price. }\end{array}$ \\
\hline \multirow{2}{*}{$\begin{array}{l}\text { Based on realisation } \\
\text { method (Krishna 2010; } \\
\text { Narahari and Huyar 2010) }\end{array}$} & English & $\begin{array}{l}\text { Tenders are submitted by bidders (contrac- } \\
\text { tors) who want to win the auction (the price } \\
\text { rises as bidders compete). }\end{array}$ \\
\hline & Dutch & $\begin{array}{l}\text { Tender is submitted by a candidate interested } \\
\text { in selling. The value is gradually reduced unti } \\
\text { there is willingness on the part of buyers (the } \\
\text { price on an item is lowered until it gets a bid). }\end{array}$ \\
\hline \multirow{2}{*}{$\begin{array}{l}\text { Based on a number of } \\
\text { criteria (Sičáková Beblavá } \\
\text { et al. 2011) }\end{array}$} & $\begin{array}{l}\text { Single- } \\
\text { criterion }\end{array}$ & The criterion is usually price. \\
\hline & Multi-criterion & $\begin{array}{l}\text { The criterion is a combination of price and } \\
\text { other factors (e.g. quality, delivery time, war- } \\
\text { ranty, after-sales service etc.). }\end{array}$ \\
\hline \multirow{2}{*}{$\begin{array}{l}\text { Based on termination } \\
\text { method (Jap 2002, 508) }\end{array}$} & Soft-close & $\begin{array}{l}\text { After submission of the last offer the defined } \\
\text { auction period is prolonged by a predeter- } \\
\text { mined time. }\end{array}$ \\
\hline & Hard-close & $\begin{array}{l}\text { The duration of the auction is strictly defined, } \\
\text { no prolongation is possible. }\end{array}$ \\
\hline
\end{tabular}

Source: Poliak 2013

In Slovakia electronic auction, or its abbreviated form e-auction, is a commonly used term for e-procurement. According to the Public Procurement Act No. $263 / 1999$ Coll. e-auction can be characterized as a repetitive process that uses elec- 
tronic devices to submit new prices revised downwards and/or new values concerning certain items and parts of tenders. Under this law an e-auction is only a part of e-procurement but in the condition of the Slovak Republic it is the most used part (up to 2014 there were 88,872 realized e-auctions with 1,700 participating subjects with a volume of 8.2 billion EUR, based on information from www.proebiz.sk) and for contracts with a small value the e-auction is actually the complete e-procurement process. Therefore, we further refer to e-procurement with the term e-auction. Basic types of e-auctions are summarized in Table 1.

Based on the research and publications of several authors (Delina, Vajda and Bolha 2008; Kaplan et al. 2007; Meričková et al. 2008; Sičáková-Beblavá et al. 2011; Thai 2001; Turban 2006) there are several advantages to e-auction use in general. Specific benefits of e-auction use can be divided into two relatively homogenous groups:

1) Increased efficiency in the services provision by reducing production costs through the promotion of the competitiveness of services in the public-procurement process and reducing the costs of public procurement through computerization of the procurement process.

2) Increased efficiency in the inspection of public-resource use by increasing the transparency of the procurement process over its whole duration.

The e-procurement in the public sector is proven to be beneficial by many of the above-mentioned studies and researchers. The question thus is how to promote the e-procurement adaptation in public organizations. Based on a literature review (Nemec and Murray Svidronova 2016) there are several factors that determine the use of public e-procurement.

\section{Methods}

The objective of this study is to identify the drivers and barriers of e-procurement use in Slovak municipalities. Given the stated objective we formulated the research question: What are the factors determining public-electronic-procurement use at the local level?

We have chosen a research question, not a hypothesis, due to the availability of data and the size of the research sample that cannot be statistically tested, i.e. would not be able to validate a hypothesis based on the sample size, so we use the research question, which is to be validated in the analytical part of this paper.

Our decision was to conduct a pilot study on the situation in one selected region in Slovakia (in total 38 municipalities -4 towns and 34 villages). However, during the research we discovered that only six municipalities realize e-procurement on a sufficient scale as an in-house activity. From this small sample four municipali- 
ties agreed to co-operate. The sample of municipalities cannot be considered to be an exhaustive list; however, we have to consider the fact the many municipalities use e-procurement (e-auctions) through external agencies and only in a limited range.

The key methods of scientific research are methods of classification analysis, comparison and abstraction in developing the theoretical and methodological framework of the public e-procurement issue; methods of causal analysis and comparison in identification of the research presumption and methods of synthesis and incomplete induction in drawing the conclusions of research. Primary data was collected by a structured questionnaire with the mayors of the selected municipalities and supplemented by secondary data from the official websites of the municipalities from the sample.

For the analysis of e-procurement use in the public sector at the local level we coordinated our research with the methodology proposed by the Bocconi University as a leader of the fifth work package, which is focused on the adoption, diffusion and upscaling of ICT-driven innovations in the LIPSE research project. The study involves a comparison of six countries (Italy, France, Spain, the Netherlands, Romania, Slovakia) which present different degrees of ICT readiness: i.e. pioneers, early adopters, followers, late adopters or laggards in ICT-driven innovations, specifically e-procurement. The analysis uses both qualitative and quantitative methods, e.g. document analysis to develop a theoretical framework that addresses the role of upscaling in the diffusion and adoption of ICT innovations, to analyze the ICT readiness of the countries and to analyze possible drivers and barriers of eprocurement implementation and use. These drivers and barriers are implied by factors of the outer and inner contexts of public institution that determine the use of public e-procurement (Nemec and Murray Svidroňová 2016, LIPSE research project methodology).

These factors can be divided as shown in Table 2.

The factors identified in the theoretical framework were analyzed by means of data gathered in primary research for e-procurement use, where we interviewed procurement officers in the sample. 
Table 2

Factors influencing e-procurement use in organizations of the public sector

\begin{tabular}{|c|c|c|}
\hline \multirow{6}{*}{ 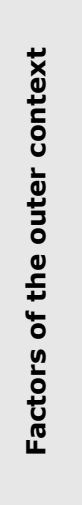 } & $\begin{array}{l}\text { Inter- } \\
\text { institutional } \\
\text { dynamics }\end{array}$ & $\begin{array}{l}\text { presence of similar entities within the same context, inter- } \\
\text { jurisdictional competition, isomorphism and mimicking }\end{array}$ \\
\hline & Economic factors & $\begin{array}{l}\text { positive association between the wealth of the community and } \\
\text { the adoption/diffusion of ICT-driven social innovation }\end{array}$ \\
\hline & Social factors & $\begin{array}{l}\text { population's education, citizens' cultural well-being, pressures } \\
\text { from public opinion and need-based demands }\end{array}$ \\
\hline & Political factors & $\begin{array}{l}\text { degree of political competition, degree of decentralization, and } \\
\text { the parliamentary/governmental stability }\end{array}$ \\
\hline & \begin{tabular}{|l|} 
Demographic \\
factors \\
\end{tabular} & $\begin{array}{l}\text { the larger the population, the more likely the adoption and } \\
\text { diffusion of ICT innovation }\end{array}$ \\
\hline & $\begin{array}{l}\text { Technological } \\
\text { factors }\end{array}$ & infrastructural capacity and ICT readiness \\
\hline \multirow{3}{*}{ 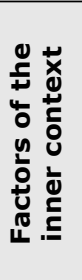 } & $\begin{array}{l}\text { Organizational } \\
\text { factors }\end{array}$ & $\begin{array}{l}\text { slack resources, management characteristics (managerial } \\
\text { leadership, visionary and support), culture of risk aversion }\end{array}$ \\
\hline & $\begin{array}{l}\text { Individual } \\
\text { factors }\end{array}$ & $\begin{array}{l}\text { employees' perceptions of ICT innovations, attitude towards } \\
\text { the technology of employees and managers, public officials' } \\
\text { autonomy and willingness to participate }\end{array}$ \\
\hline & $\begin{array}{l}\text { Technological } \\
\text { factors }\end{array}$ & $\begin{array}{l}\text { compatibility, adaptability, complexity, accessibility, security } \\
\text { and reliability of ICT used, Internet/Intranet availability }\end{array}$ \\
\hline
\end{tabular}

Source: authors, based on Nemec and Murray Svidroňová 2016.

\section{Use of e-procurement in selected municipalities in Slovakia}

The implementation of e-auctions by municipalities to the procurement process is determined by the entry into force of the Act No. 58/2011 Coll., which amended Act No. 25/2006 Coll. on Public Procurement (Public Procurement Act). Following this amendment, it was established for the public sector to use e-auctions for contracts below a defined limit (from 40,000 to 200,000 euros). Before this amendment the obligation to use e-auction was solely on over-limit contracts.

From the municipalities in our research sample, the first municipality that began to use e-auctions in public procurement was the town of Martin in 2009, i.e. this town started using e-auctions even before it was forced to by law. The other three municipalities wished to stay anonymous, and they adopted e-auctions in 2011 and later.

In this part we summarize the results of interviews with mayors of the municipalities that use e-procurement on their own, without employing any external agency. As mentioned already, the pioneer among the municipalities was the town of Martin, the other towns were followers. The mayors of the participating towns were asked to identify the factors based on their influence on e-procurement imple- 
mentation, where " + " means the factor is a driver, stimulating the implementation process, " 0 " is an irrelevant factor that did not influence the process and "-" is a barrier, slowing down the process of e-procurement implementation.

Table 3

Influence of determinants and barriers of the outer and inner context at the local level

\begin{tabular}{|c|c|c|c|c|c|}
\hline & & 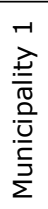 & 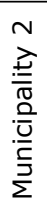 & 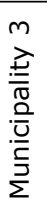 & 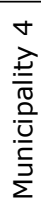 \\
\hline \multirow{7}{*}{$\begin{array}{l}\text { Factors of the outer } \\
\text { context }\end{array}$} & Inter-institutional dynamics & + & + & + & + \\
\hline & Legislative factors & + & + & 0 & + \\
\hline & Political factors & + & 0 & 0 & + \\
\hline & Social factors & + & + & + & + \\
\hline & Economic factors & + & + & + & + \\
\hline & Demographic factors & 0 & 0 & 0 & 0 \\
\hline & Technological factors & + & + & 0 & + \\
\hline \multirow{3}{*}{$\begin{array}{l}\text { Factors of the inner } \\
\text { context }\end{array}$} & Organizational factors & + & 0 & 0 & 0 \\
\hline & Individual factors & 0 & 0 & 0 & 0 \\
\hline & Technological factors & + & + & 0 & + \\
\hline
\end{tabular}

Source: authors

At the local level, the factors of the outer context that are considered to be drivers are mostly inter-institutional dynamics (the imitation of other e-procurement experiences drives its adoption by public-sector organizations). The legislative factors can also be considered the drivers. Legislative obligations and standards drive the adoption of e-procurement in public-sector organizations. Political factors (political vision for e-procurement facilitates its adoption in public-sector organizations, conflicts among public institutions and/or political parties as a barrier to the adoption of e-procurement in public-sector organizations) seems to be less important as the drivers. Social factors (population's education, citizens' cultural well-being, pressures from public opinion and need-based demands) and economic factors (sufficient financial, human and IT sources, allocation of public finance into this area) can be considered important drivers of e-procurement implementation and use.

Factors of the inner context, which facilitate the e-procurement use the most, are technological factors, e.g. IT compatibility and capacity, safety and complexity of e-procurement system. None of the factors were considered to be barriers for eprocurement implementation. 
When compared with the regional level (see Nemec and Murray Svidroňová 2016), we can see that a rather strong driver is the imitation of other e-procurement experiences by public-sector organizations, i.e. the introduction of e-procurement may be a motivational example for organizations of the public sector at the local/regional level.

\section{Discussion}

Public e-procurement should enhance not only the transparency of public procurement but also the competition between the participants by increasing the number of foreign participants or SMEs. Thanks to the computerization of the public-procurement process there is a possibility of cross-border participation in public procurement. Increasing the number of participants increases the competition between them, and increasing the number of candidates from abroad also limits a potential monopoly of an individual company in a country or region.

The sample of four municipalities is small, but if we look at results, the sample seems to characterize the situation in Slovakia. Too small municipalities do not purchase in house, larger ones cope with very similar problems. Because of this, we can argue that the results of this pilot research cover the situation of e-procurement use at the local level in all of Slovakia.

The results of our analysis have shown that the use of public e-procurement at the local level is evaluated very positively. It is implemented mostly in order to increase transparency and cost effectiveness. It is in the hands of individuals (procurement officers, managers, employees) how e-procurement will be implemented in the public sector, which is the determinant of the inner context. Indeed, based on the responses, the factors of employees' technological skills and the possibility of trainings and other supportive activities have a strong influence on e-procurement adoption. Employees of municipalities basically have rather low technical skills, and they are not so fast when working with information and communication technologies. In most cases, especially in smaller municipalities, employees are of older age and with a certain degree of aversion to the ICT innovations introduced into the municipality management system. The administration of the e-procurement process requires skills in the use of ICT and thus we would recommend more training for ICT use. This can be set by the management of municipalities, as managers with good leadership also have a strong impact on e-procurement adoption, and from their position they can facilitate trainings for employees and influence their perception of e-procurement.

But also determinants of the outer context showed to be rather influential factors in the analysis. These factors were mostly imitation of other e-procurement experiences by public-sector organizations and territorial ICT infrastructures, such as the broadband connection having to be strengthened to facilitate the adoption. Therefore 
we would recommend strengthening territorial ICT infrastructures, e.g. making a high-quality connection available for all municipalities. Based on the analysis of other determinants of the outer context, we can conclude that the legislative and sociopolitical environment is prepared for the e-procurement adoption (barriers like law regulations or budget constraints were evaluated as low, i.e. the respondents disagree that these barriers frustrate e-procurement adoption in Slovakia).

On the other hand, e-procurement makes the municipalities cope with a high degree of bureaucracy. As a negative aspect the personnel workload was mentioned as well as frequent legislative changes that municipalities with fewer workers have difficulties to embrace. Electronic public procurement thus requires changes so that also smaller entities, such as municipalities, could use the e-procurement effectively and efficiently.

\section{Conclusion}

Some solutions in simplifying the e-procurement can be seen in the so-called electronic marketplace. In Slovakia, the electronic marketplace (e-market) was launched on 1 February 2015 and is obligatory to be used by all state authorities and public institutions, governments at higher territorial units (regions) and municipalities. Also legal persons, who are established, managed, financed and controlled by government and public entities will procure through e-market. The minimum limit for shopping via the e-market is $1000 €$. The upper limit in the case of state institutions is $134,000 €$, for other entities $207,000 €$ for goods and services. For construction work the upper limit is 5,186,000€. Placement of orders on the e-market can be done by selecting from catalogue offers (electronic catalogue) or defining a placement electronically. In both cases a 72-hour period (in case of complicated trade to be appropriately prolonged) of anonymous bidding takes place; competition of suppliers results in a reduction of the price of the contract subject. The idea is to increase transparency, i.e. visibility and clarity of public procurement when all information about the contract, its process, the procurer and the contractor will be available on the web (Nemec and Murray Svidroňová 2016).

The e-market also provides the possibility of active and successful participation in the competition for public contracts to SMEs with a regional and local scope. Till now the procurement process was too complicated for small and medium enterprises to take part in it. The establishment of the e-market might help to increase the adoption and use of e-procurement at the regional level (regional procurement officers will be more in favour of e-procurement).

In this paper we focused on e-procurement implementation and use in Slovak municipalities. Despite the small sample we feel that we have very representative answers to the research question. The results show the main drivers and barriers of e-procurement use at the local level in selected municipalities of our pilot research. 
Based on structured interviews we identified the factors of the outer context (the imitation of other e-procurement experiences drives its adoption by public-sector organizations, legislative obligations and standards as well as social factors as drivers, political factors as a barrier) and the factors of the inner context (technological factors as drivers, no factors as barriers). Future research could aim not only at factors that determine the use of e-procurement but also at quantifying cost efficiency by using e-auctions in contracting-out.

\section{Acknowledgement}

This paper was published as a part of two research projects: LIPSE - Learning from Innovation in Public Sector Environments and GA16-13119S - Performance management in public administration - theory vs. practices in the Czech Republic and other CEE countries.

\section{References}

Act No. 25/2006 Coll. on Public Procurement, as amended.

Benčina, J. and T. Jukić. 2015. "How to Assess Whether Qualified Evaluations of e-Government Projects Are Conducted? The Case of Slovenia." International Public Administration Review 13(3-4), 235-255.

Christensen, T. and P. Lægreid. 2001. "New Public Management: The Effects of Contractualism and Devolution on Political Control." Public Management Review 3(1), 73-94.

Coombes, D. and T. Verheijen (eds). 1997. Public Management Reform: Comparative Experiences from East and West. Brussels: European Commission.

Covaleski, M. A., M. W. Dirsmith and K. L. Mantzke. 2005. "Institutional Destabilisation and the New Public Management: The Case of Tax Incremental Financing." International Journal of Public Policy 1(1-2), 122-147.

Delina, R., Vajda, V., Bolha, J.2008. Elektronický obchod v slovenskom priemysle. Sektorová štúdia v strojárskom a chemickom priemysle. Grafotlač Prešov, 2008, ISBN 978-80-969953-1-8.

European Commission. 2010. GREEN PAPER on expanding the use of e-Procurement in the EU, SEC (2010) 1214.

Gavurová, B., R. Štefko and R. Bačík. 2014. “The Analysis of Social Services’ Structure in a Specific Region and its Significance for Health and Social Policy in Slovakia." Polish Journal of Management Studies 10(2), 43-53. 
Hardy, C. A. and S. P. Williams. 2008. "E-government Policy and Practice: A Theoretical and Empirical Exploration of Public E-procurement." Government Information Quarterly 25(2), 155-180.

Hvozdíková, V., B. Hošoff and T. Jeck. 2011. Analýza priorít národnej politiky v oblasti informačno-komunikačných technológií. Bratislava: Ekonomický ústav SAV.

Joia, L. A. and F. Zamot. 2002. "Internet-Based Reverse Auctions by the Brazilian Government." The Electronic Journal on Information Systems in Developing Countries 9(6), 1-12.

Jukić, T., M. Vintar and J. Benčina. 2013. "Ex-ante Evaluation: Towards an Assessment Model of its Impact on the Success of E-government Projects." Information Polity 18(4), 343-361.

Kaplan, M., Zrník, J. et al. 2007. Firemní nákup a e-aukce. Jak setřit čas a peníze. Praha : Grada Publishing a.s. 2007. 216 s. ISBN 978-80-247-2002-9.

Kuvíková, H. and G. Vaceková. 2009. "Diverzifikácia finančných zdrojov v neziskových organizáciách" [Diversification of financial sources in non-profit organizations]. E \& M Ekonomie a Management 12(4), 84-95.

Loader, K. 2011. "Are Public Sector Procurement Models and Practices Hindering Small and Medium Suppliers?" Public Money \& Management 31(4), 287-294.

Major, C. 2003. Reverse auctions - A Suitable Procurement Tool for the WA Public Sector? Available at http://www.finance.wa.gov.au/cms/uploadedFiles/Government_Procurement/Publications/Professional_Papers_and_Presentations/reverse_auctions.pdf? $\mathrm{n}=5254$ (last accessed 20 April 2016).

Mereles, D. 2012. Reinventing Procurement in Paraguay: Introducing Electronic Reverse Auctions. Available at http://api.ning.com/files/lZ4CXhFTngp1DQNQ pHsfrTolFrw7leMPZLik2 $w^{*}$ yFWAufbcKZopwNeF9NwHxdmTq2bZ999PV -OWWebInH ${ }^{\star} Z W 9$ ePxluo ${ }^{\star}$ ERNW/ParaguayPubliceProcurement_final.pdf (last accessed 20 April 2016).

Meričková, B., J. Nemec and F. Ochrana. 2008. "Introducing Benchmarking in the Czech Republic and Slovakia: Processes, Problems and Lessons." Public Management Review 10(5), 673-684.

Meričková, B., J. Nemec and L. Vítek. 2005. "Contracting-out at Local Government Level: Theory and Selected Evidence from Czech and Slovak Republics." Public Management Review 7(4), 637-647.

Michalski, G. 2008. "Value-based Inventory Management." Journal of Economic Forecasting 9(1), 82-90.

Murray, J. G. 2012. "Debate: Revolutionizing or Recycling Public Procurement Policy in the UK?" Public Money \& Management 32(3), 165-167. 
Murray, J. G. 2014. "Debate: Public Procurement Needs Outcome Evaluations." Public Money \& Management 34(2), 141-143.

Murray Svidroňová, M. and T. Mikuš. 2015. "E-procurement as the ICT Innovation in the Public Services Management: Case of Slovakia." Journal of Public Procurement 15(3), 317-340.

Nemec, J. 2010. "New Public Management and its Implementation in CEE: What Do we Know and where Do we Go?" NISPAcee Journal of Public Administration and Policy 3(1), 31-52.

Nemec, J. and M. Murray Svidroňová. 2016. "Factors Influencing e-Procurement Use in Self-Governing Regions in Slovakia." Lex localis - Journal of Local SelfGovernment, 2016, forthcoming.

Ochrana, F., J. Nemec and M. Šumpíková. 2008. "Czech and Slovak Lessons for Public Administration Performance Evaluation, Management and Finance." Journal of Economics 4, 353-369.

Pavel, J. and E. Sičáková-Beblavá. 2008. “Transparency of Public Procurement Market in the Czech Republic and Slovakia." Ekonomický časopis 2(56), 168-181.

Pavel, J. et al. 2013. "Do e-Auctions Really Improve the Efficiency of Public Procurement? The Case of the Slovak Municipalities." Prague Economic Papers 22(1), 111-124.

Poliak, L. 2013. "Elektronické aukcie ako spôsob zabezpečovania verejných statkov v podmienkach obcí SR - súčasný stav a perspektívy" [Electronic auctions as a way of securing public goods in terms of municipalities in Slovakia - current status and prospects]. In P. Slavićková (ed.). Sborník z mezinárodni vědecké konference Znalosti pro tržní praxi 2013, Veřejná ekonomika - současnost a perspektiva konané 12.-13. záŕí 2013 v Olomouci. Olomouc: Societas Scientiarum Olomoucensis II, 48-54.

Sashi, C. M. and B. O'Leary. 2002. "The Role of Internet Auctions in the Expansion of B2B Markets." Industrial Marketing Management 31(2), 103-110.

Savoldelli, A., G. Misuraca and C. Codagnone. 2013. "Measuring the Public Value of e-Government: The eGEP 2.0 Model." Electronic Journal of e-Government 11(1), 373-388.

Sičáková-Beblavá, E., S. Šatníková and P. Klátik. 2011. Elektronické aukcie vo verejnom obstarávaní: teória a prax na Slovensku [Electronic auctions in public procurement: theory and practice in Slovakia]. Bratislava: Transparency International.

Špaček, D. and I. Malý. 2010. "E-Government Evaluation and its Practice in the Czech Republic: Challenges of Synergies." The NISPAcee Journal of Public Administration and Policy 3(1), 93-124. 
Tatnall, A. and A. Gilding. 1999. "Actor-Network Theory and Information Systems Research." In P. Yoong and B. Hope (eds.). Proceedings of the $10^{\text {th }}$ Australasian Conference on Information Systems. Wellington: Victoria University of Wellington. School of Communications and Information Management, 955-966.

Tátrai, T. 2015. "Debate: Cutback Management through Public Procurement." Public Money \& Management 35(4), 255-256. DOI:10.1080/09540962.2015.104 7265 .

Thai, K. V. 2001. "Public Procurement Re-examined." Journal of Public Procurement $1(1), 9-50$.

Trenkler, T. 2011. Elektronické obstarávanie (e-aukcie) čast’ 1. Available at http:// videoserver.cnl.tuke.sk/elektronicke_obstaravanie_eaukcie_cast_i.pdf (last accessed 10 February 2016).

Turban, E. et. al. 2006. Electronic Commerce. A Managerial Perspective, New Jersey: Pearson Education, Inc., 2006. 792 s. ISBN 0-13-185461-5.

Twum-Darko, M. 2014. "Factors Influencing Readiness for Transformational eGovernment: A Perspective of Local Governments in South Africa." Journal of Public Administration 49(2), 512-523.

Welch, E. W., C. C. Hinnant and M. J. Moon. 2005. "Linking Citizen Satisfaction with e-Government and Trust in Government." Journal of Public Administration Research and Theory 15(3), 371-391.

World Bank. 2010. Assessment of the Procurement Systems of the Brazilian Federal Government and the Brazilian State of São Paulo. Available at www.worldbank.org (last accessed 20 April 2016).

Wyld, D. C. 2011. Saving Time and Money through Reverse Auctions: A Case Study on the Efficiency of Competitive Bidding Utilization at the U.S. Department of State. Available at http://media.wix.com/ugd/8ea413_7ff66a2016ff6cee85bc1 81fa6d326c0.pdf (last accessed 20 April 2016). 